\title{
Study of Hygrothermal Processes in External Walls with Internal Insulation
}

\author{
Edite BISENIECE ${ }^{1 *}$, Ritvars FREIMANIS ${ }^{2}$, Reinis PURVINS ${ }^{3}$, Armands GRAVELSINS $^{4}$, \\ Aivars PUMPURS ${ }^{5}$, Andra BLUMBERGA ${ }^{6}$ \\ ${ }^{1-4,6}$ Institute of Energy Systems and Environment, Riga Technical University \\ Azenes iela 12/1, Riga, LV-1048, Latvia \\ ${ }^{5}$ Institute of Industrial Electronics and Electrical Engineering, Riga Technical University, \\ Azenes iela 12/1, Riga, LV-1048, Latvia
}

\begin{abstract}
Being an important contributor to the final energy consumption, historic buildings built before 1945 have high specific heating energy consumption compared to current energy standards and norms. However, they often cannot be insulated from the outside due to their heritage and culture value. Internal insulation is an alternative. However internal insulation faces challenges related to hygrothermal behaviour leading to mold growth, freezing, deterioration and other risks. The goal of this research is to link hygrothermal simulation results with experimental results for internally insulated historic brick masonry to assess correlation between simulated and measured data as well as the most influential parameters. The study is carried out by both a mathematical simulation tool and laboratory tests of historic masonry with internal insulation with four insulation materials (mineral wool, EPS, wood fiber and granulated aerogel) in a cold climate (average 4000 heating degree days). We found disparity between measured and simulated hygrothermal performance of studied constructions due to differences in material parameters and initial conditions of materials. The latter plays a more important role than material parameters. Under a steady state of conditions, the condensate tolerating system varies between $72.7 \%$ and $80.5 \%$ relative humidity, but in condensate limiting systems relative humidity variates between $73.3 \%$ and $82.3 \%$. The temperature between the masonry wall and all insulation materials has stabilized on average at $+10{ }^{\circ} \mathrm{C}$. Mold corresponding to Mold index 3 was discovered on wood fiber mat.
\end{abstract}

Keywords - Energy efficiency in buildings; historic buildings; internal insulation; mold growth

\section{INTRODUCTION}

With climate changes broadly witnessed, cannot afford to use more energy than we need. Today $40 \%$ of total energy consumption in the European Union comes from the building sector [1], [2]. The European Union's research project RIBuild defines historic buildings as buildings built before 1945 and reports that more than $30 \%$ of final energy consumed by the building sector is allocated to historic buildings [3]. For example, in Latvia more than $50 \%$ of the housing stock heated area belongs to multifamily apartment buildings, and out of that about $26 \%$ are built before 1940 [4]. Reduction of energy consumption in existing building stock is one of the European Union's energy and climate policy tools [5]. Retrofit of the existing building stock gives significant contribution in reduction of greenhouse gas emissions and overall sustainability of the building stock [6].

\footnotetext{
* Corresponding author.

E-mail address: edite.kamendere@rtu.lv
} 
Insulation of external walls is an effective way to reduce energy consumption in buildings. The principles that should be followed when external walls are insulated include the air tightness of the wall, and the vapour permeability which should increase gradually towards the outside surface of the wall [7]. Although the best and the most reliable way to install external wall insulation is insulation from the outside, preservation of the facades of historic buildings prohibits external insulation in this way. Moreover, there might be other reasons why insulation from the outside is not possible such as space restrictions, aesthetic reasons, etc. An alternative solution to insulating the external wall from the outside is to insulate it from the inside. However, this is associated with risks caused by changes in the hygrothermal behaviour in the wall. When insulation is applied on the internal surface of the wall, both temperature and moisture conditions are changed within the wall, exposing it to several risks such as condensation, mold growth, freezing, deterioration, algae growth, etc. Each of these risks occurs under different hygrothermal conditions depending on the material properties, e.g. the study carried out by Purvins et al. found that fully saturated clay bricks used in historic building start to crack after two freeze-thaw cycles [8], while the study of Pasek and Kesl showed that Central Europe's climatic conditions presented high risk of structural damages for historic stone and brick masonry with internal insulation due to temperature changes [9]. Thus assessment of the technical condition of the building prior to application of internal insulation is an important activity which helps to determine the most appropriate retrofit methods and materials as well as helps to avoid or minimize problems associated with moisture [10].

Hygrothermal behaviour of internally insulated walls can be assessed either by simulation or experimentally. Mathematical models of heat and moisture transport tools, such as well know Delphin [11] or WUFI [12] can help to predict hygrothermal behaviour of building envelope. Nevertheless, accuracy of results from mathematical models depends on the quality of input data. Databases contain hygric and thermal parameters of certain materials obtained from laboratory tests and differ from other materials which are not tested in the laboratory. They also take into account parameters that are not known. Experimental tests can be carried out either in a controlled environment in a laboratory or on site in actual buildings.

A number of studies have been carried out on laboratory tests of different materials applied on the internal side of historic walls. Wurtz and Saelle tested two new types of thermal breakers designed for internal application in historical buildings, and the results showed that $60 \%$ of heat loss reduction can be reached by using both of the thermal breakers [13]. Haupl and Fechner described the methodology on how to determine moisture storage and moisture transport properties in the capillary active insulation material which is widely used for internal insulation of historic buildings [14]. Vereecken and Roels tested eleven different types of insulation materials on the massive masonry wall under the steady-state conditions. Vapour tight systems showed the best performance and capillary active insulation systems with glue mortar showed the worse performance due to accumulation of water in the mortar [15]. Pavlik and Cerny in their study with mineral wool insulation showed that, by applying mineral wool on a brick wall, it performs well while applying it on the argillite wall, the overhygroscopic moisture is present in the wall [16]. Other research showed that vacuum panels as an internal insulation in historic buildings cause higher relative humidity in the wooden beam ends, even more so, when wind driven rain is present, the relative humidity in the wall rises substantially [17]. A non-insulated zone of $300 \mathrm{~mm}$ above and below the floor is proposed for buildings with floor beams. This kind of solution is proposed to avoid moisture build up for buildings located in humid climates [18]. 
A limited number of papers are available on heat transfer and moisture transport in-situ measurements in historic buildings which have internal wall insulation. In Latvia Biseniece et al., tested two types of insulation materials: aerogel and vacuum insulation panel. Test results showed that the temperature between the wall and internal insulation drop to $-9.32{ }^{\circ} \mathrm{C}$ in case of vacuum panel and $-7.08{ }^{\circ} \mathrm{C}$ in case of aerogel. They also concluded that energy savings cannot be reached if special attention is not paid to energy management issues, and that calcium silicate masonry faces the freeze-thaw risk if the capillary saturation reaches into the brick during the below zero outdoor conditions [19]. In Estonia Kloseiko et al., monitored a double leaf rubble exterior wall of a museum building with internal insulation. Insulation was installed during the autumn-winter period and consisted of an air cavity, mineral wool and a newly built inner leaf. During the period of monitoring, very high relative humidity was observed. The research led to the conclusion that drying of the masonry wall before insulation should be taken into account and neglect to do so will cause overall high relative humidity levels throughout the structure and potential risk of mold growth [20]. In another research carried out in Estonia by Kloseiko et al., four different insulation materials (polyurethane, polisocyanurate, aerated concrete and calcium silicate) were tested. Test results showed that calcium silicate and aerated concrete dried out faster than the other two materials, but they also showed rapid increase of moisture, when the humidity of the internal climate was increased. The main conclusion was that built in moisture of the wall during the application of the insulation is responsible for high humidity levels and can cause interstitial condensation [21]. Similar research was carried out by Pavia where seven types of insulation materials were tested on the wall of historic brick. Those materials where compared to the lime plaster finish. It was found out that by an average of $13 \%$ to $25 \%$ the performance of the insulation materials is overestimated by producers [22]. Bianco et al. have carried out the investigation on new thermal insulating plaster and studied this material on a historic building in Turin, Italy. The preliminary results show that thermal conductivity of proposed new plaster is 2.5 to 3 times lower than conventional plaster, but more research is needed on the long-term performance of this material [23]. Galliano et al. have carried out simulations and measurements of two new internal insulation materials [24].

Literature review on internal insulation of historic masonry walls revealed that studies are scattered and no common solution for all the different cases exists. Each of the studies have different goals mainly focusing on thermal behaviour of the wall and much less on the moisture transport. Selection of the right insulation system or material for the specific case is crucial and sometimes in order to avoid moisture problems it is better to sacrifice a bit of energy efficiency. A better understanding of the hygrothermal behaviour of internally insulated walls needs to be obtained.

The goal of this research is to link hygrothermal simulation results with experimental results for internally insulated historic brick masonry to assess correlation between simulated and measured data as well as the most influential parameters. The study is carried out through the application of both a mathematical simulation tool and laboratory tests of historic masonry built from bricks produced around 1900 with internal insulation with four insulation materials in cold climates (average outdoor temperature in heating season $0{ }^{\circ} \mathrm{C}$ and 200 heating days annually). The paper starts with an introduction, is followed by description of materials, applied methodology, analysis of results and finally, discussions and conclusions. 


\section{BASE WALL AND INTERNAL INSULATION MATERIALS}

The experimental set-up was built in the laboratory. Four types of insulation materials, two types of vapour barriers, gypsum board and historic bricks were used in this study.

The base wall was built from historic bricks collected from the demolition site of a historic building built around 1900 at O. Vācieša iela 6, Riga, Latvia. Lime-cement mortar was used. The base wall samples were built as double leaf masonry with the size of $25 \mathrm{~cm} \times 28 \mathrm{~cm}$ and the depth of $51 \mathrm{~cm}$ each.

Expanded polystyrene board, wood fiber board, mineral (rock) wool and granulated aerogel LA1000 were used for internal insulation. Expanded polystyrene board and mineral wool are widely used and common insulation materials. Nowadays natural materials such as wood fiber board and innovative materials, e.g. granulated aerogel are becoming more popular. Vapour barriers with different equivalent air layer thicknesses ( $s_{\mathrm{d}}$ values) were used. All materials and their technical parameters are listed in Table 1.

TABLE 1. TeChNiCAL PARAMETERS OF TESTED InSUlation MATERIALS

\begin{tabular}{|c|c|c|c|c|c|c|}
\hline $\begin{array}{l}\text { Insulation } \\
\text { material }\end{array}$ & Thickness, $\mathrm{m}$ & $\begin{array}{l}\text { Heat } \\
\text { conductivity, } \\
\mathrm{W} /(\mathrm{mK})\end{array}$ & $\begin{array}{l}\text { Bulk } \\
\text { density, } \\
\mathrm{kg} / \mathrm{m}^{3}\end{array}$ & $\begin{array}{l}\text { Vapour } \\
\text { resistance } \\
\text { coefficient } \mu\end{array}$ & $s_{\mathrm{d}}$ values, $\mathrm{m}$ & Manufacturer \\
\hline $\begin{array}{l}\text { Expanded } \\
\text { polystyrene board }\end{array}$ & 0.05 & 0.039 & 13.5 & 30 & 1.5 & $\begin{array}{l}\text { Tenapors } \\
\text { (Tenax) }\end{array}$ \\
\hline Wood fiber board & 0.05 & 0.038 & 50 & 2.1 & 0.105 & Steico group \\
\hline Mineral wool & 0.05 & 0.036 & 28 & 1 & 0.05 & Paroc \\
\hline $\begin{array}{l}\text { Granulated } \\
\text { aerogel }\end{array}$ & 0.02 & 0.016 & $65-85$ & N/A & N/A & $\begin{array}{l}\text { Cabot } \\
\text { corporation }\end{array}$ \\
\hline Gypsum board & 0.018 & 0.21 & 732 & 6.8 & 0.122 & Norgips \\
\hline Vapour barrier (1) & N/A & N/A & N/A & N/A & 4.5 & Elkatek \\
\hline Vapour barrier (2) & N/A & N/A & N/A & N/A & 12 & Jutadach \\
\hline
\end{tabular}

Although many insulation materials are available on the market, it is still not clear which of them can be applied safely internally. Insulation materials can be distinguished by different parameters. In the scope of this study materials are grouped by parameters attributed to interstitial condensate. In accordance to the basic properties and following WTA 6-4 [25] and DIN 4108-3 [26], insulation materials can be divided into three groups:

- Condensate-preventing insulation systems disable vapour transfer from the room side into the construction by a vapour barrier. Vapour barriers are sealing layers with a vapour diffusion equivalent air layer thickness $s_{\mathrm{d}}$ of minimum $1500 \mathrm{~m}$;

- Condensate-limiting insulation systems include a vapour brake with an $s_{\mathrm{d}}$ value of minimum $0.5 \mathrm{~m}$ and maximum $1500 \mathrm{~m}$. Vapour control layer should reduce the vapour input from the room side into the construction and has to be combined with a sufficient wind-driven rain protection;

- Condensate-tolerating insulation systems consist of capillary active insulation material and glue mortar. The only vapour resistance in these insulation systems is given by the material itself, therefore they show very small vapour transfer resistances $\left(s_{\mathrm{d}}\right.$ value $<$ $0.5 \mathrm{~m})$.

Types of insulation systems used in the tests are presented in Table 2. 
TABLE 2. TYPES OF INSULATION SYSTEMS

\begin{tabular}{llllll}
\hline Test Round & Insulation material & Vapour barrier & $\begin{array}{l}\text { Finishing } \\
\text { material }\end{array}$ & $\begin{array}{l}\text { System } s_{\mathrm{d}} \\
\text { value, } \mathrm{m}\end{array}$ & Insulation system type \\
\hline Test round 1 & Wood fiber & $\begin{array}{l}\text { Vapour barrier } \\
(1)\end{array}$ & Gypsum board & 4.73 & Condensate tolerating \\
Test round 1 & Mineral wool & $\begin{array}{l}\text { Vapour barrier } \\
(1)\end{array}$ & Gypsum board & 4.67 & Condensate limiting \\
Test round 1 & EPS & NO & Gypsum board & 1.62 & Condensate limiting \\
Test round 1 & Granulated aerogel & $\begin{array}{l}\text { Vapour barrier } \\
(1)\end{array}$ & Gypsum board & N/A & N/A \\
Test round 2 & Wood fiber & NO & Gypsum board & 0.23 & Condensate tolerating \\
Test round 2 & Mineral wool & $\begin{array}{l}\text { Vapour barrier } \\
(2)\end{array}$ & Gypsum board & 12.17 & Condensate limiting \\
Test round 2 & EPS & NO & Gypsum board & 1.62 & Condensate limiting \\
Test round 2 & Granulated aerogel & NO & Gypsum board & N/A & N/A \\
\hline
\end{tabular}

\section{Methodology}

The study was carried out by two methods: simulation of hygrothermal behaviour with heat and transfer simulation tool Delphin 5.9.3. [11], and measurement of hygrothermal parameters of internally insulated masonry wall in the laboratory. The simulation was performed before and after laboratory tests to assess correlation between measured and simulated data, and perform analysis of parameters that affect the fit between the simulation results and measured results.

\subsection{Tests of Bricks}

Ten randomly selected bricks were tested to assess density and open porosity. Open porosity was determined based on standard EN 772-3:1998 [27]. Dry density of bricks was measured based on standard EN 772-13:2000 [28].

\subsection{Heat and Moisture Transfer Model}

The 2-dimensional hygrothermal behaviour in transient conditions of the base wall and three different insulation materials (granulated aerogel was not simulated as it is not available in the material database) was analyzed. The wall is composed of 2-dimensional layers (see Fig. 1).

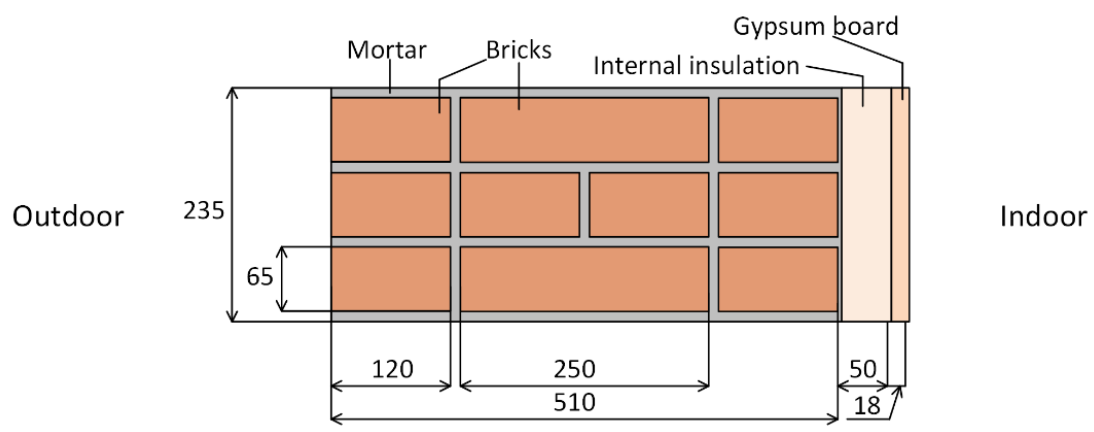

Fig. 1. 2-dimensional model of simulated masonry wall with internal insulation (all numbers are in mm). 
Only density and open porosity of bricks were derived from the material tests in the laboratory prior to the experiment (see Chapter 3.1). These two parameters were used as decisive values to select brick from the Delphin database. Lime-cement mortar, mineral wool, wood fiber and EPS were selected from the Delphin database. Before the laboratory experiment the simulation was performed for insulated masonry with data from the Delphin database (see Table 3).

TABLE 3. PROPERTIES OF MATERIALS USED

FOR SIMULATION BEFORE LABORATORY EXPERIMENT

\begin{tabular}{|c|c|c|c|c|c|c|}
\hline & & Brick & Mortar & $\begin{array}{l}\text { Mineral } \\
\text { wool }\end{array}$ & Wood fiber & EPS \\
\hline \multicolumn{2}{|c|}{$\begin{array}{l}\text { Name of the material in } \\
\text { Delphin database }\end{array}$} & $\begin{array}{l}\text { Old building } \\
\text { brick Dresden } \\
\text { ZD }\end{array}$ & $\begin{array}{l}\text { Lime } \\
\text { cement } \\
\text { mortar }\end{array}$ & $\begin{array}{l}\text { Mineral } \\
\text { Wool }\end{array}$ & $\begin{array}{l}\text { Wood Fiber } \\
\text { Insulation } \\
\text { Board }\end{array}$ & $\begin{array}{l}\text { Polystyrene } \\
\text { Board - } \\
\text { Expanded }\end{array}$ \\
\hline \multicolumn{2}{|c|}{ Density of dry material, $\mathrm{kg} / \mathrm{m}^{3}$} & 1619.51 & 1878.47 & 37 & 150 & 23 \\
\hline \multicolumn{2}{|c|}{ Open porosity, $\mathrm{m}^{3} / \mathrm{m}^{3}$} & 0.388864 & 0.291144 & 0.92 & 0.981 & 0.93 \\
\hline \multicolumn{2}{|c|}{ Thermal conductivity, $\mathrm{W} /(\mathrm{mK})$} & 0.4025 & 0.803333 & 0.04 & 0.042 & 0.036 \\
\hline \multicolumn{2}{|c|}{$\begin{array}{l}\text { Specific heat capacity of dry } \\
\text { material, J/kg }\end{array}$} & 953.143 & 757.939 & 840 & 2000 & 1500 \\
\hline \multicolumn{2}{|c|}{$\begin{array}{l}\text { Water vapour diffusion } \\
\text { resistance factor }\end{array}$} & 10.4726 & 36.9113 & 1 & 3 & 96 \\
\hline \multicolumn{2}{|c|}{$\begin{array}{l}\text { Water uptake coefficient, } \\
\mathrm{kg} / \mathrm{m}^{2} \mathrm{~s}^{0.5}\end{array}$} & 0.380526 & 0.036085 & 0 & 0.07 & 0.00001 \\
\hline \multicolumn{2}{|c|}{$\begin{array}{l}\text { Effective saturation (long term } \\
\text { process), } \mathrm{m}^{3} / \mathrm{m}^{3}\end{array}$} & 0.361043 & 0.222606 & 0.9 & 0.6 & 0.92 \\
\hline \multicolumn{2}{|c|}{$\begin{array}{l}\text { Capillary saturation content } \\
\text { (short term process), } \mathrm{m}^{3} / \mathrm{m}^{3}\end{array}$} & 0.2563 & 0.2166 & 0.9 & 0.55 & - \\
\hline \multicolumn{2}{|c|}{$\begin{array}{l}\text { Liquid water conductivity at } \\
\text { effective saturation, s }\end{array}$} & $2.09 \mathrm{E}-09$ & $1.02 \mathrm{E}-11$ & 0 & $2.16 \mathrm{E}-08$ & 0 \\
\hline \multirow{6}{*}{ 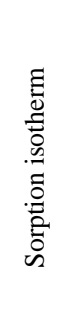 } & $\begin{array}{l}\text { Moisture } \\
\text { content, } \\
\mathrm{m}^{3} / \mathrm{m}^{3}\end{array}$ & 0.001912 & $6.29 \mathrm{E}-08$ & N/A & 0.0000683 & 0.0000528 \\
\hline & RH $30 \%$ & 0.003322 & 0.01011 & - & 0.0048476 & 0.000455 \\
\hline & RH $50 \%$ & 0.003445 & 0.035014 & - & 0.0080606 & 0.000617 \\
\hline & RH $80 \%$ & 0.003662 & 0.060304 & - & 0.0176992 & 0.001078 \\
\hline & RH $95 \%$ & 0.011130 & 0.083608 & - & 0.0328964 & 0.009227 \\
\hline & RH $100 \%$ & 0.361043 & 0.222606 & - & 0.6 & 0.92 \\
\hline \multicolumn{2}{|c|}{$\begin{array}{l}\text { Initial relative humidity within } \\
\text { material, } \%\end{array}$} & 40 & 40 & 40 & 40 & 40 \\
\hline \multicolumn{2}{|c|}{$\begin{array}{l}\text { Initial temperature of material, } \\
{ }^{\circ} \mathrm{C}\end{array}$} & 23 & 23 & 23 & 23 & 23 \\
\hline
\end{tabular}

Boundary conditions used for simulation before the laboratory experiments: indoor temperature $+20{ }^{\circ} \mathrm{C}$ and relative humidity $55 \%$, and outdoor temperature $+3{ }^{\circ} \mathrm{C}$ and $85 \%$ relative humidity. For the simulation after experiment, boundary conditions were used as in experimental test rounds. 


\subsection{Hygrothermal Behaviour Tests of the Test Wall}

In the Baltic Sea region the common historic building consists of three to seven stories and has 45-90 cm thick brick wall [7]. For the hygrothermal behaviour tests of the test wall a double climatic chamber in laboratory was used. A test wall with four double leaf masonry patterns $(25 \mathrm{~cm} \times 28 \mathrm{~cm} \times 51 \mathrm{~cm})$ was built and inserted inside this chamber (see Fig. 2).

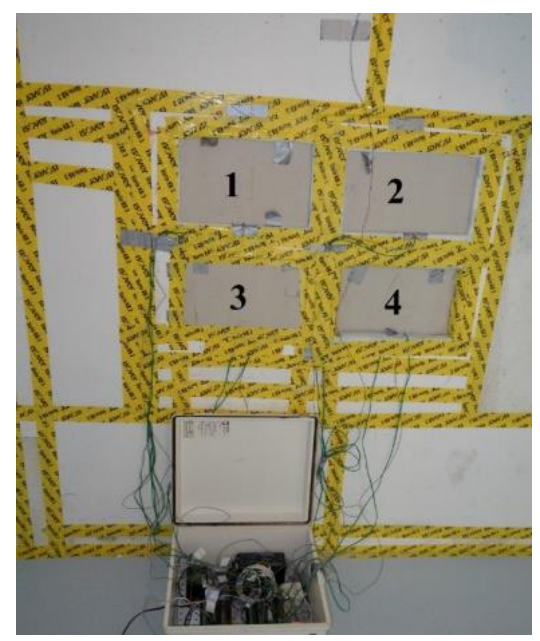

Fig. 2. Laboratory test stand with four historic masonry patterns and four insulation materials: 1 - wood fiber, 2 - mineral wool, 3 - expanded polystirene board, 4 - granulated aerogel.

Relative humidity and temperature were measured between insulation and masonry (on the middle of the brick), and in both chambers with 8 temperature sensors and 5 relative humidity sensors. Time step of both measurements is 1 minute.

Two test rounds were carried out (see Table 4). During the first test series the data monitoring equipment failed on the first day of the test run and data were collected from the second day of testing. The first test round was carried out for 22 days. The second round was carried out after drying the test wall in room condition for 8 days. The second test round took 23 days. Outdoor chamber conditions were changed for the second test round because humidifier was freezing in the first test round.

\section{TABLE 4. TEST CONDITIONS OF TEST ROUNDS}

\begin{tabular}{lll}
\hline Test conditions & Test 1 & Test 2 \\
\hline $\begin{array}{l}\text { Preconditioning period length, days } \\
\text { Preconditioning temperature/relative }\end{array}$ & 10 & 8 \\
humidity & $+23{ }^{\circ} \mathrm{C} / 25 \%$ & Room conditions \\
Length of the test, days & 22 & 23 \\
Indoor temperature/relative humidity & $+19.5{ }^{\circ} \mathrm{C}$ to $+20.5{ }^{\circ} \mathrm{C} / 53-56 \%$ & $+19.5{ }^{\circ} \mathrm{C}$ to $+20.5{ }^{\circ} \mathrm{C} / 53-56 \%$ \\
Outdoor temperature/relative humidity & $-0.5{ }^{\circ} \mathrm{C}$ to $+0.5{ }^{\circ} \mathrm{C} / 80-90 \%$ & $+2.5{ }^{\circ} \mathrm{C}$ to $+3.5^{\circ} \mathrm{C} / 80-90 \%$ \\
\hline
\end{tabular}

Every masonry pattern was insulated with a different type of insulation system: expanded polystirene board, wood fiber board, mineral wool with vapour barrier $\left(s_{\mathrm{d}}\right.$ in the first test round 
was $4.5 \mathrm{~m}$ and in the second test round was $12 \mathrm{~m})$ and translucent hydrophobic granulated aerogel $(0.7-4.0 \mathrm{~mm})$ (detailed information see in Table 2). The thickness of insulation materials was selected based on the average U-value of $0.35 \mathrm{~W} /\left(\mathrm{m}^{2} \mathrm{~K}\right)$ for all four patterns. All patterns were covered with gypsum board from the indoor side.

\section{RESUlts}

\subsection{Tests of Bricks}

Fig. 3 illustrates test results of density and open porosity of historic bricks used in the test wall. There is no correlation found between these two parameters with $\mathrm{R}^{2}$ value only 0.0896 . The average open porosity is $35.86 \%$ and density is $1611.1 \mathrm{~kg} / \mathrm{m}^{3}$.

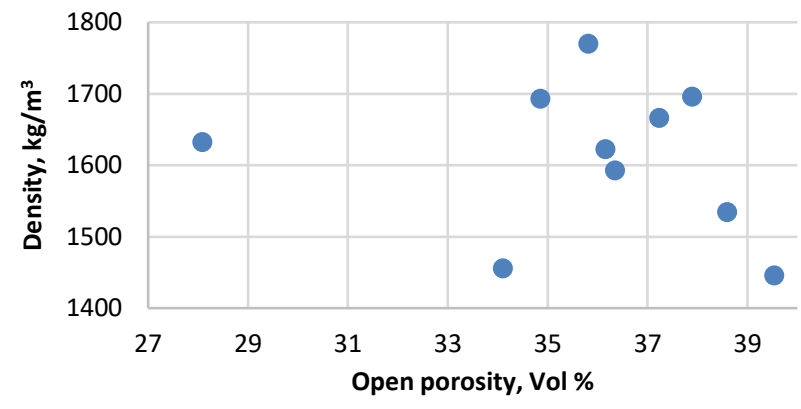

Fig. 3. Open porosity and density of tested historic bricks.

\subsection{Hygrothermal Simulation before Laboratory Experiment}

The relative humidity and temperature between masonry and insulation material in three simulated wall constructions are presented in Fig. 4. Both relative humidity and temperature changes at slow rate asymptotically approaching equilibrium conditions only on 14th day for mineral wool, 17th day for EPS and 21st day for wood fiber. All three samples stabilize at different temperatures: $11.55{ }^{\circ} \mathrm{C}$ for wood fiber, $10.44{ }^{\circ} \mathrm{C}$ for EPS and $10.37{ }^{\circ} \mathrm{C}$ for mineral wool. The equilibrium relative humidity also differs and is $39.1 \%$ for mineral wool, $43.9 \%$ for EPS and $71.4 \%$ for wood fiber.

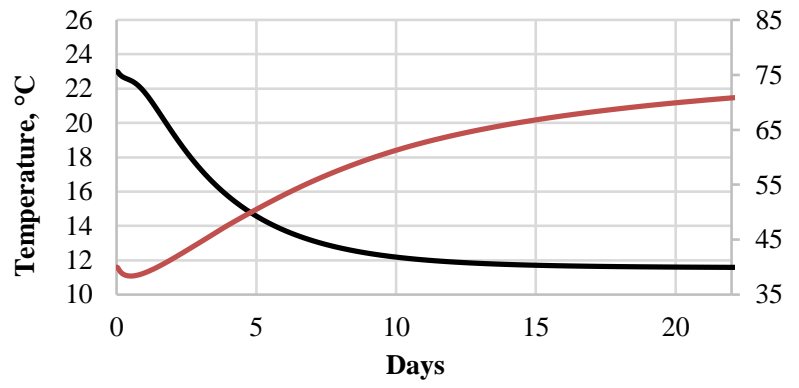

(a)

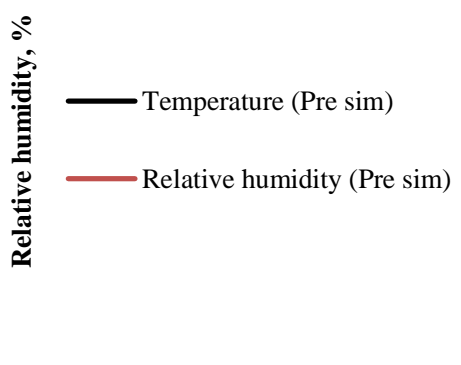




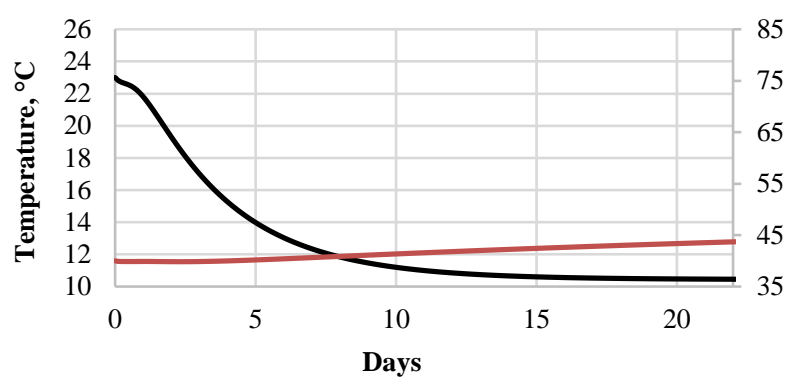

(b)

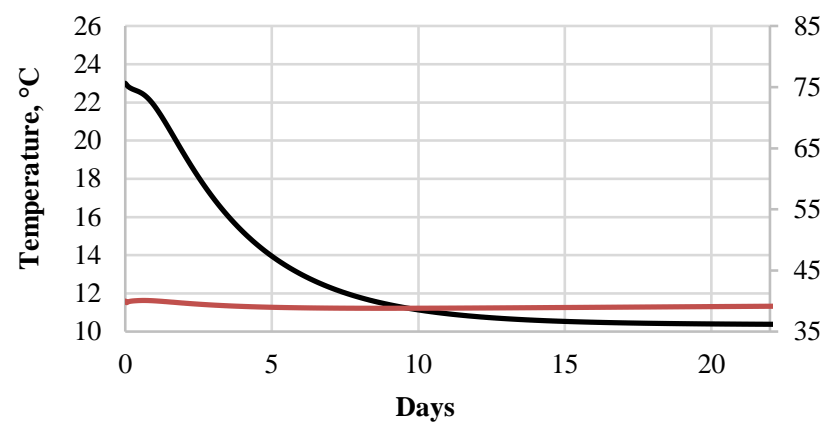

(c)
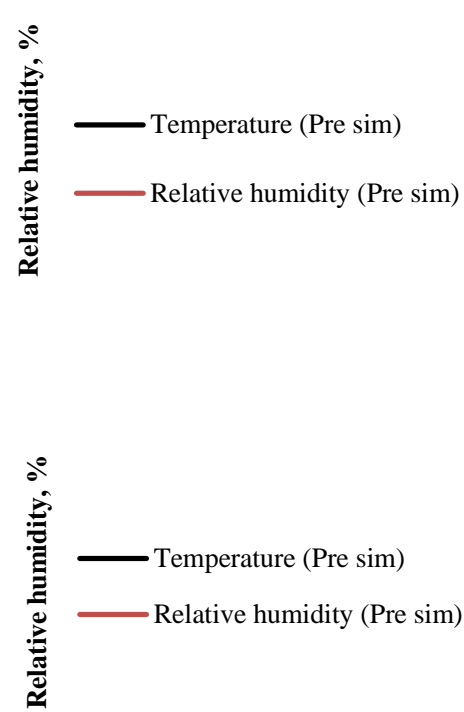

Fig. 4. Simulated temperature and relative humidity between masonry and insulation layer before experiment: a) wood fiber, b) EPS, c) mineral wool.

\subsection{Hygrothermal Behaviour of the Test Wall}

The relative humidity and temperature between masonry and insulation material in four tested wall patterns measured in both test rounds is shown in Fig. 5. Relative humidity growth rate is high during first five test days for all materials and is slowing down when approaching equilibrium conditions. Temperature for all samples is reaching equilibrium in the first 5 days.

Relative humidity between masonry and the wood fiber (see Fig. 5(a)) is higher when the vapour barrier is not applied and reaches $80 \%$ while if the vapour barrier is installed relative humidity increases up to $74 \%$. The growth rate of relative humidity is also higher without the vapour barrier. The initial temperatures are different for both tests but they stabilize after five days at $+11.3{ }^{\circ} \mathrm{C}$ for the sample with vapour barrier and at $+9.45{ }^{\circ} \mathrm{C}$ without vapour barrier.

Mineral wool with two different vapour barrier types (see Fig. 5(b)) show the same trend of behaviour of relative humidity and they both reach $83.5 \%$ at the end of the test. The growth rate of relative humidity is very high during first two days and stabilizes thereafter. The initial temperatures are different for both tests but they stabilize after five days at $+9.7^{\circ} \mathrm{C}$ for the first test and at $+10.8{ }^{\circ} \mathrm{C}$ for the second test.

EPS (see Fig. 5(c)) shows the same trend of behaviour of relative humidity for both tests reaching $80 \%$ at the end of the test. The growth rate of relative humidity is very high during first two days and stabilizes after that. The initial temperatures are different for both tests but they stabilize after five days at $+9{ }^{\circ} \mathrm{C}$ for the first test and at $+10.7^{\circ} \mathrm{C}$ for the second test.

When the vapour barrier is applied to granulated aerogel (see Fig. 5(d)) the relative humidity increases very quickly during the first two days and increases up to $79 \%$ during the next 20 
days. If aerogel is used without the vapour barrier, relative humidity is lower (74 \%). Temperatures are $+9.8^{\circ} \mathrm{C}$ and $+11^{\circ} \mathrm{C}$, respectively.

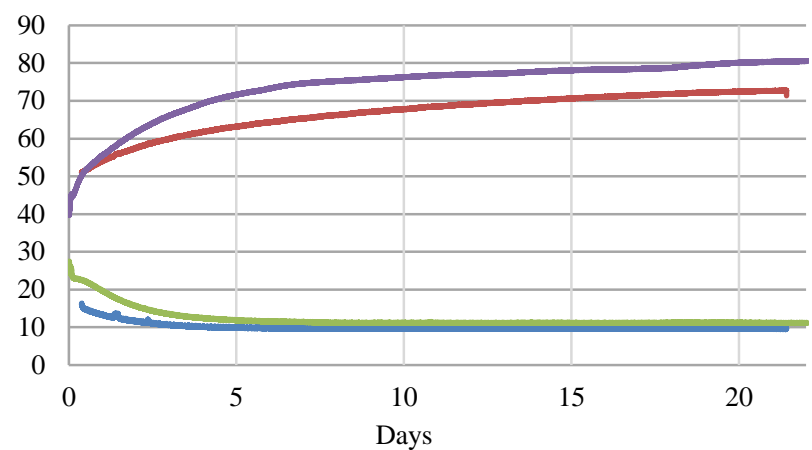

(a)

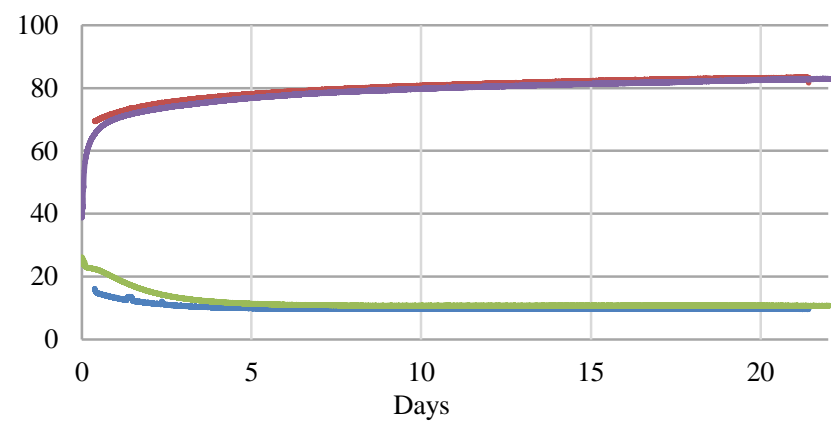

(b)

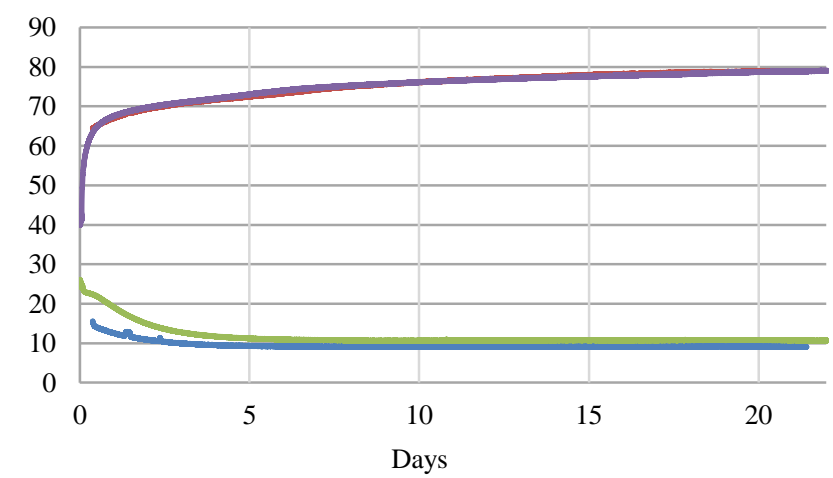

(c)
Temperature: test $1,{ }^{\circ} \mathrm{C}$

Relative humidity: test1, \%

- Temperature: test $2,{ }^{\circ} \mathrm{C}$

Relative humidity: test $2, \%$

- Temperature: test $1,{ }^{\circ} \mathrm{C}$

Relative humidity: test1, \% Temperature: test $2,{ }^{\circ} \mathrm{C}$

Relative humidity: test $2, \%$

Temperature: test $1,{ }^{\circ} \mathrm{C}$

Relative humidity: test1, \%

Temperature: test $2,{ }^{\circ} \mathrm{C}$

Relative humidity: test $2, \%$ 


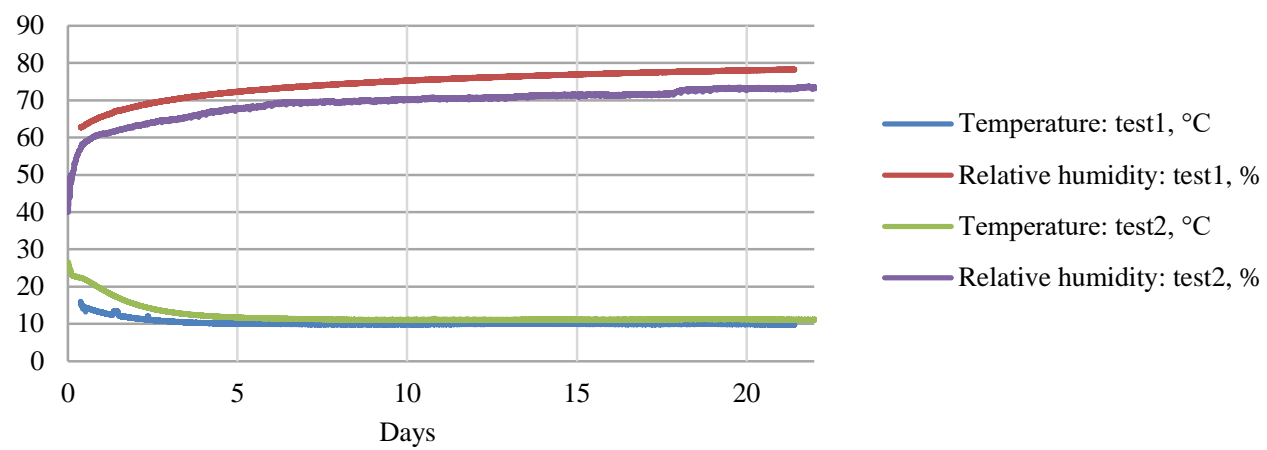

(d)

Fig. 5. Measured temperature and relative humidity between masonry and insulation layer: a) wood fiber, b) mineral wool, c) EPS, d) granulated aerogel.

\subsection{Mold Growth}

Mold growth is one the major risks associated with internal insulation as the hygrothermal conditions are favourable for spore germination and further mycelium growth. If there are enough nutrients and time for germination, a high risk of mold growth exists. Fig. 6 illustrates development of the Lowest Isopleth for Mold from Isopleth of different species for both spore germination and mycelium growth.

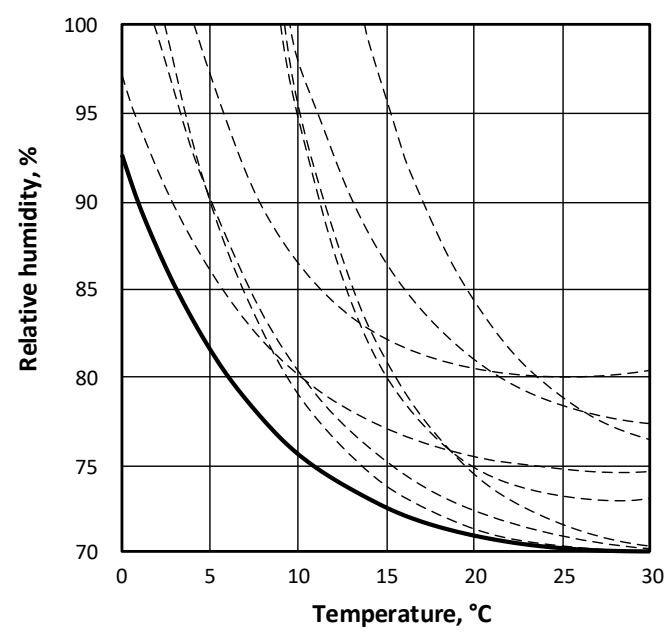

(a)

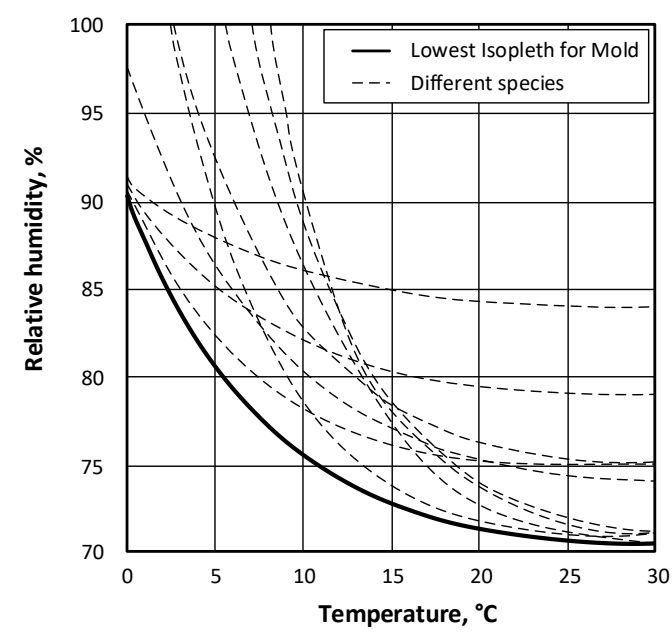

(b)

Fig. 6. The Lowest Isopleth for Mold of different species for spore germination (a) and mycelium growth (b) [29].

If the temperature is $+10{ }^{\circ} \mathrm{C}$ and there are enough nutrients and time, spore germination and mycelium growth starts at $76 \%$ relative humidity (see Fig. 6). In both test rounds temperature stabilized around $+10{ }^{\circ} \mathrm{C}$ and relative humidity was above $76 \%$ for all insulation materials. When the test wall was opened on the 22nd day after the beginning of the test, mold was discovered on one of the corners of the wood fiber mat. According to [5] wood fiber is substrate class I (biodegradable materials) with higher fungal growth rate and it 22 days was enough to 
have visible fungal growth on the wood fiber. This corresponds to mold index level 3 by VTT Mold Growth model (visual findings of mold on surface, $<10 \%$ coverage) when new spores are produced [30]. Fig. 7 illustrates wood fiber affected by mold and magnified material with and without mold on it. After the second test round mold was discovered in the middle of the insulation material.

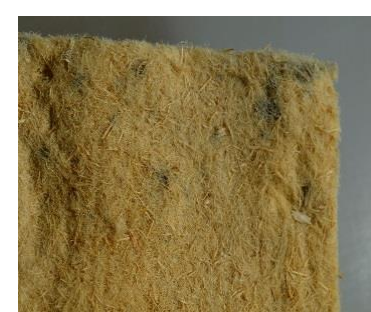

(a)

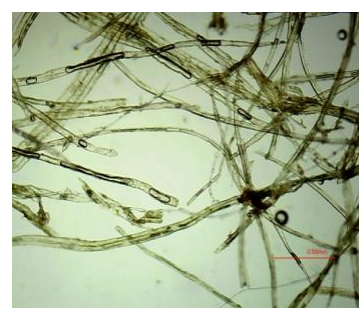

(b)

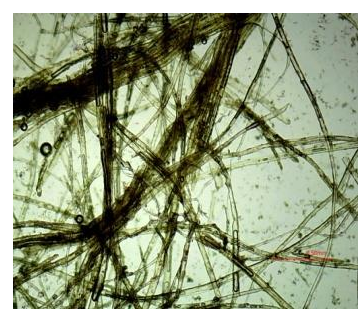

(c)

Fig. 7. Mold on wood fiber mat after test: a) mold on the top right corner, b) magnified wood fiber without mold, c) with mold.

\subsection{Comparison of Experimental and Hygrothermal Simulation Results}

Correlation analysis presented in Fig. 8 shows that satisfactory results are reached for temperature as correlation coefficient $\mathrm{R}^{2}$ is in the range of 0.81 to 0.86 . Correlation is good for simulated and measured results for relative humidity of wood fiber $\left(\mathrm{R}^{2}=0.84\right)$, but good correlation is not reached for relative humidity for EPS $\left(R^{2}=0.59\right)$ and mineral wool $\left(R^{2}=0.54\right)$.

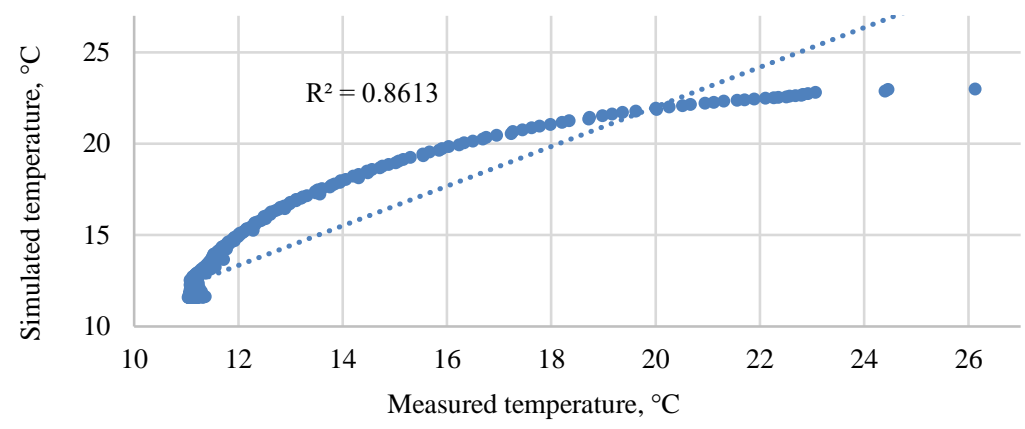

(a)

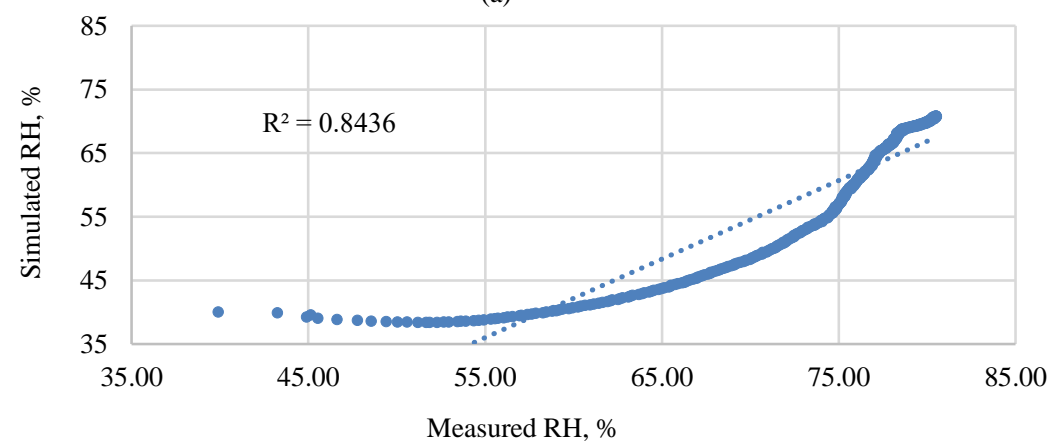

(b) 


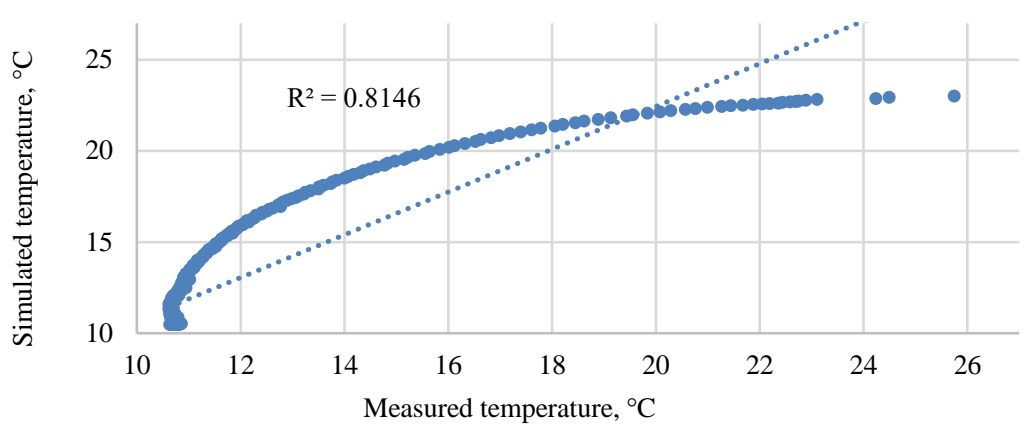

(c)

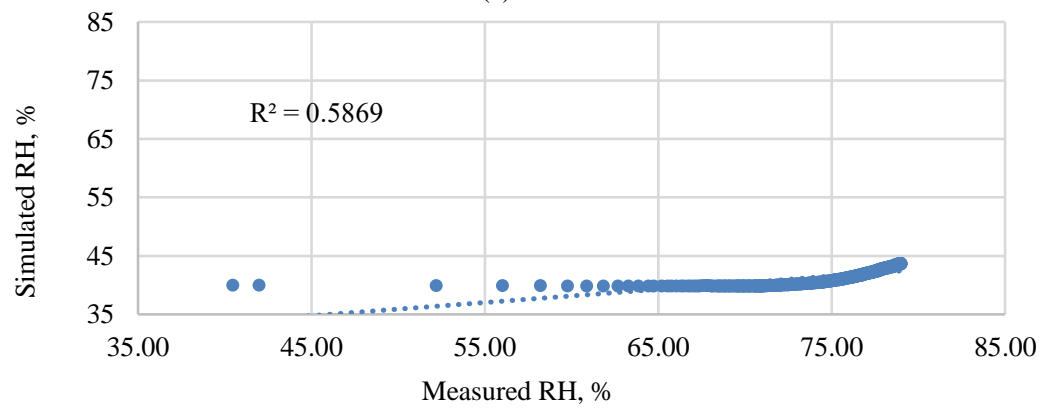

(d)

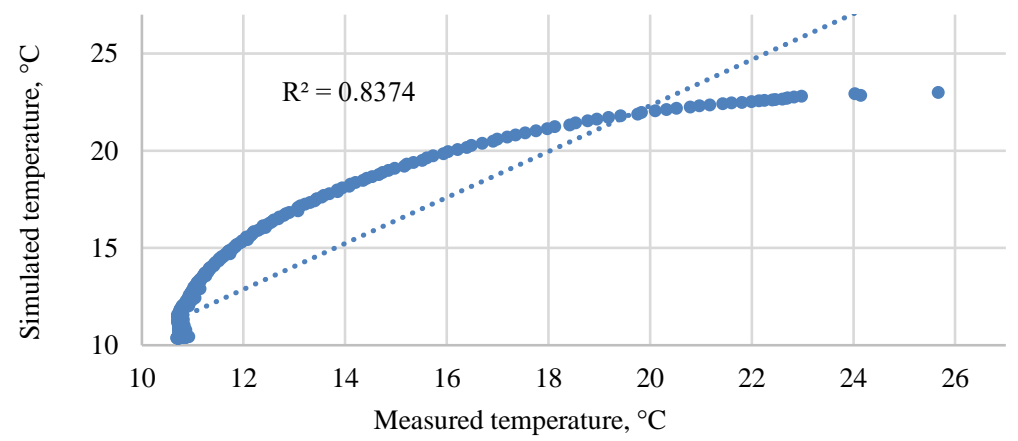

(e)

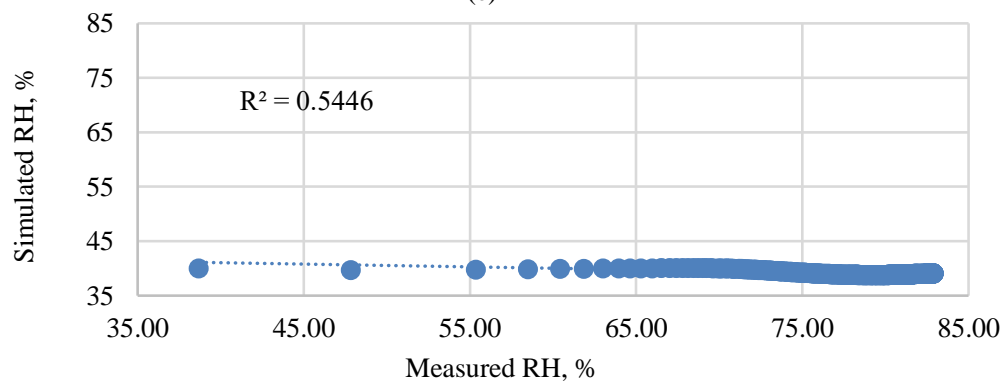

(f)

Fig. 8. Correlation between simulated and measured temperatures: a) wood fiber, c) EPS, e) mineral wool. Relative humidity: b) wood fiber, d) EPS, f) mineral wool (between masonry and insulation layer). 
Model fitting to measured data was improved by applying the parametric analysis. It was carried out by modifying parameters of masonry, mortar and insulation materials. Thermal conductivity, density of dry material, and water vapour diffusion resistance factor for insulation materials were changed to values supplied by material producers (see Table 1). For bricks and mortar thermal conductivity, specific heat capacity, liquid water conductivity at effective saturation, water uptake coefficient and initial relative humidity were adjusted. Adjusted values are presented in Table 5.

TABLE 5. PROPERTIES OF MATERIALS USED FOR PARAMETRIC ANALYSIS

\begin{tabular}{|c|c|c|c|c|c|c|}
\hline & & Brick & Mortar & $\begin{array}{l}\text { Mineral } \\
\text { wool }\end{array}$ & Wood fiber & EPS \\
\hline \multicolumn{2}{|c|}{$\begin{array}{l}\text { Name of the material in } \\
\text { Delphin database }\end{array}$} & $\begin{array}{l}\text { Old building } \\
\text { brick Dresden } \\
\text { ZD }\end{array}$ & $\begin{array}{l}\text { Lime } \\
\text { cement } \\
\text { mortar }\end{array}$ & $\begin{array}{l}\text { Mineral } \\
\text { Wool }\end{array}$ & $\begin{array}{l}\text { Wood Fiber } \\
\text { Insulation } \\
\text { Board }\end{array}$ & $\begin{array}{l}\text { Polystyrene } \\
\text { Board - } \\
\text { Expanded }\end{array}$ \\
\hline \multicolumn{2}{|c|}{ Density of dry material, $\mathrm{kg} / \mathrm{m}^{3}$} & 1619.51 & 1878.47 & $28(-24 \%)$ & $50(-67 \%)$ & $13.5(-41 \%)$ \\
\hline \multicolumn{2}{|c|}{ Thermal conductivity, $\mathrm{W} /(\mathrm{mK})$} & $0.482(+20 \%)$ & $0.5(-38 \%)$ & $\begin{array}{l}0.036 \\
(-10 \%)\end{array}$ & $0.038(-10 \%)$ & $0.039(+8 \%)$ \\
\hline \multicolumn{2}{|c|}{$\begin{array}{l}\text { Specific heat capacity of dry } \\
\text { material, } \mathrm{J} / \mathrm{kg}\end{array}$} & $430(-55 \%)$ & $470(-38 \%)$ & 840 & 2000 & 1500 \\
\hline \multicolumn{2}{|c|}{$\begin{array}{l}\text { Water vapour diffusion } \\
\text { resistance factor }\end{array}$} & 10.4726 & 36.9113 & 1 & $2.1(-30 \%)$ & $30(-69 \%)$ \\
\hline \multicolumn{2}{|c|}{$\begin{array}{l}\text { Water uptake coefficient, } \\
\mathrm{kg} / \mathrm{m}^{2} \mathrm{~s}^{0.5}\end{array}$} & $\begin{array}{l}0.423587 \\
(+11 \%)\end{array}$ & $\begin{array}{l}0,211622 \\
(+486 \%)\end{array}$ & 0 & 0.07 & 0.00001 \\
\hline \multicolumn{2}{|c|}{$\begin{array}{l}\text { Effective saturation (long term } \\
\text { process), } \mathrm{m}^{3} / \mathrm{m}^{3}\end{array}$} & $\begin{array}{l}0.761043 \\
(+111 \%)\end{array}$ & $0.1(-55 \%)$ & 0.9 & 0.6 & 0.92 \\
\hline \multicolumn{2}{|c|}{$\begin{array}{l}\text { Liquid water conductivity at } \\
\text { effective saturation, s }\end{array}$} & $\begin{array}{l}2.59 \mathrm{E}-09 \\
(+24 \%)\end{array}$ & $\begin{array}{l}3.52 \mathrm{E}-10 \\
(+3339 \%)\end{array}$ & 0 & $2.16 \mathrm{E}-08$ & 0 \\
\hline \multirow{6}{*}{ 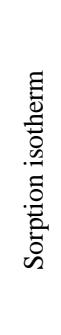 } & $\begin{array}{l}\text { Moisture } \\
\text { content, } \\
\mathrm{m}^{3} / \mathrm{m}^{3}\end{array}$ & 0.004030 & $2.83 \mathrm{E}-08$ & & 0.0000683 & 0.0000528 \\
\hline & RH $30 \%$ & 0.007003 & 0.004542 & & 0.0048476 & 0.000455 \\
\hline & RH $50 \%$ & 0.007261 & 0.015729 & & 0.0080606 & 0.000617 \\
\hline & RH $80 \%$ & 0.007720 & 0.027090 & & 0.0176992 & 0.001078 \\
\hline & RH $95 \%$ & 0.023461 & 0.037559 & & 0.0328964 & 0.009227 \\
\hline & RH $100 \%$ & 0.761043 & 0.1 & & 0.6 & 0.92 \\
\hline \multicolumn{2}{|c|}{$\begin{array}{l}\text { Initial relative humidity within } \\
\text { material, } \%\end{array}$} & $65(+62 \%)^{*}$ & $\begin{array}{l}85 \\
(+112 \%)^{*}\end{array}$ & 40 & 40 & 40 \\
\hline \multicolumn{2}{|c|}{$\begin{array}{l}\text { Initial temperature of material, } \\
{ }^{\circ} \mathrm{C}\end{array}$} & 23 & 23 & 23 & 23 & 23 \\
\hline
\end{tabular}

*Within the material starting from in the depth of $2.5 \ldots 3.5 \mathrm{~cm}$ from the external surfaces of material.

Fig. 9 illustrates the changes of temperature and relative humidity during simulation before and after the experiment, and measured results in masonry with wood fiber without vapour barrier. The main gap between measured and pre-test simulation temperatures is observed during the first 10 days when the pre-test simulation temperature is decreasing at a slower rate than measured temperature. The post-test simulation results fit well with measured temperatures. The temperature at the equilibrium differs only $0.6{ }^{\circ} \mathrm{C}$. To reach acceptable results for post-test 
simulation fit, the values of the thermal conductivity, density of dry material, and the specific heat capacity have been changed (see Table 5).

The same tendency is observed for the relative humidity: the pre-test simulation has a much lower increase rate at the beginning hence it has not reached equilibrium during the simulation period. The post-test simulation and measured relative humidity fit well and both are stabilizing at around $80 \%$. To reach acceptable results for the post-test simulation, the water vapour diffusion resistance factor, the liquid water conductivity at effective saturation, water uptake coefficient and initial relative humidity of the brick and mortar have been changed (see Table 5).

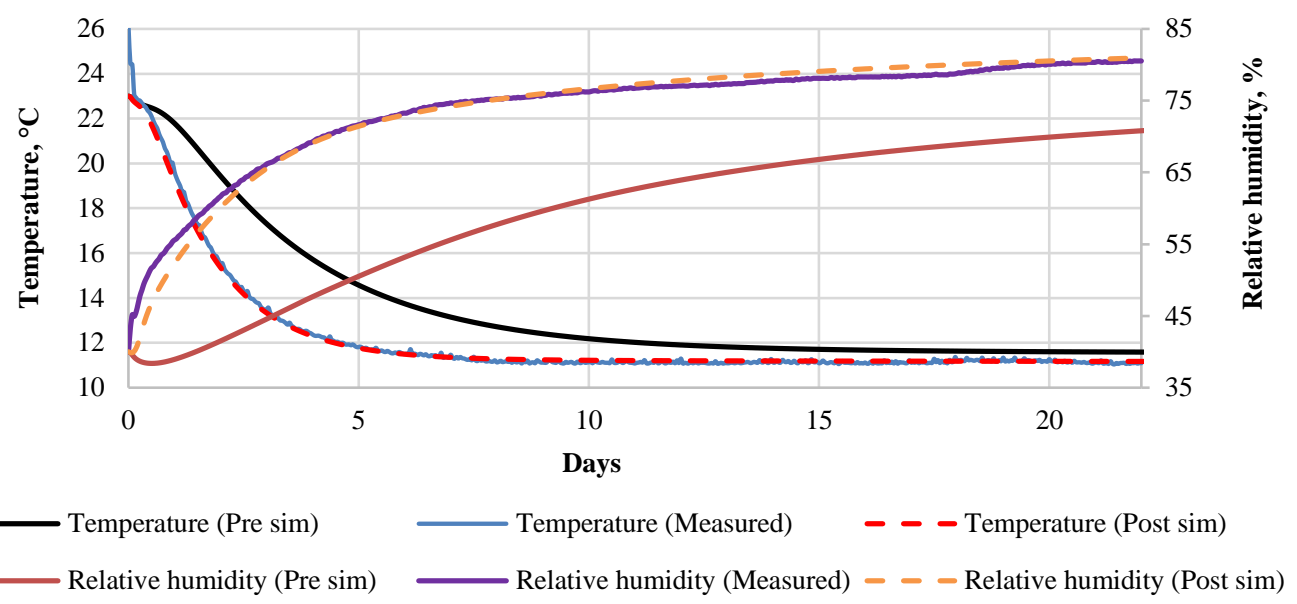

Fig. 9. Behaviour of temperature and relative humidity between masonry and wood fiber without vapour barrier insulation layer: simulation before and after experiment, and measured results.

Fig. 10 shows the changes of temperature and relative humidity during simulation before and after the experiment, and measured results between masonry and EPS insulation layer. The main gap between measured and pre-test simulation temperatures is observed during the first 10 days when the pre-test simulation temperature is decreasing at a slower rate than the measured temperature. The post-test simulation results fit well with measured temperatures. The temperature at the equilibrium fits well for all three graphs. To reach acceptable results for posttest simulation the values of the thermal conductivity, density of dry material, and the specific heat capacity have been changed (see Table 5).

The gap between measured and pre-test simulation results of relative humidity is significant. The relative humidity cannot gain the speed to increase the rate of change neither at the beginning nor during the rest of the pre-test simulation. The post-test simulation and measured relative humidity fit well and both are stabilizing around $81.5 \%$ for measurements and $83 \%$ for post-test simulation. To reach acceptable results for post-test simulation, the water vapour diffusion resistance factor, the liquid water conductivity at effective saturation, water uptake coefficient and initial relative humidity of the brick and mortar have been changed (see Table 4). 


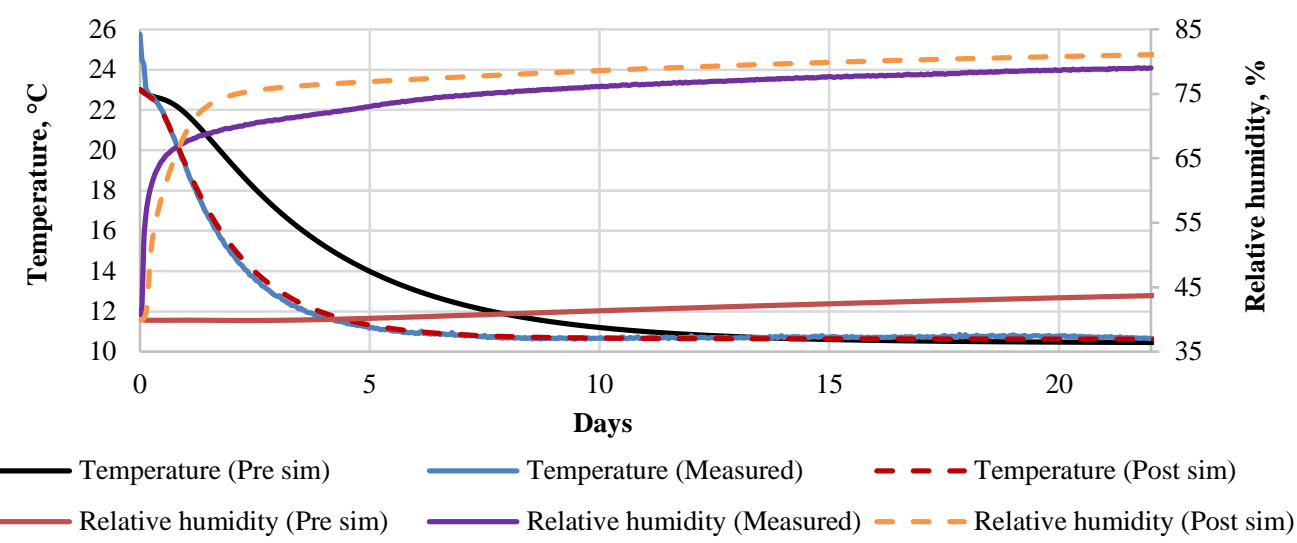

Fig. 10. Behaviour of temperature and relative humidity between masonry and EPS insulation layer: simulation before and after experiment, and measured results.

Fig. 11 shows the changes of temperature and relative humidity during simulation before and after the experiment, and measured results between masonry and mineral wool with vapour barrier $\left(s_{\mathrm{d}}=12 \mathrm{~m}\right)$ insulation layer. The main gap between measured and pre-test simulation temperatures is observed during the first 10 days when the pre-test simulation temperature is decreasing at a slower rate than the measured temperature. The post-test simulation results fit well with measured temperatures. The temperature at the equilibrium fits well for all three graphs. To reach acceptable results for post-test simulation, the values of the thermal conductivity, density of dry material, and the specific heat capacity have been changed (see Table 5).

The gap between measured and pre-test simulation results of relative humidity is large. The relative humidity cannot gain the speed to increase the rate of change neither at the beginning nor during the rest of the pre-test simulation. The post-test simulation and measured relative humidity fit well and both are stabilizing around $83 \%$ and $80.7 \%$. To reach acceptable results for post-test simulations, the water vapour diffusion resistance factor, the liquid water conductivity at effective saturation, water uptake coefficient and initial relative humidity of the brick and mortar have been changed (see Table 5).

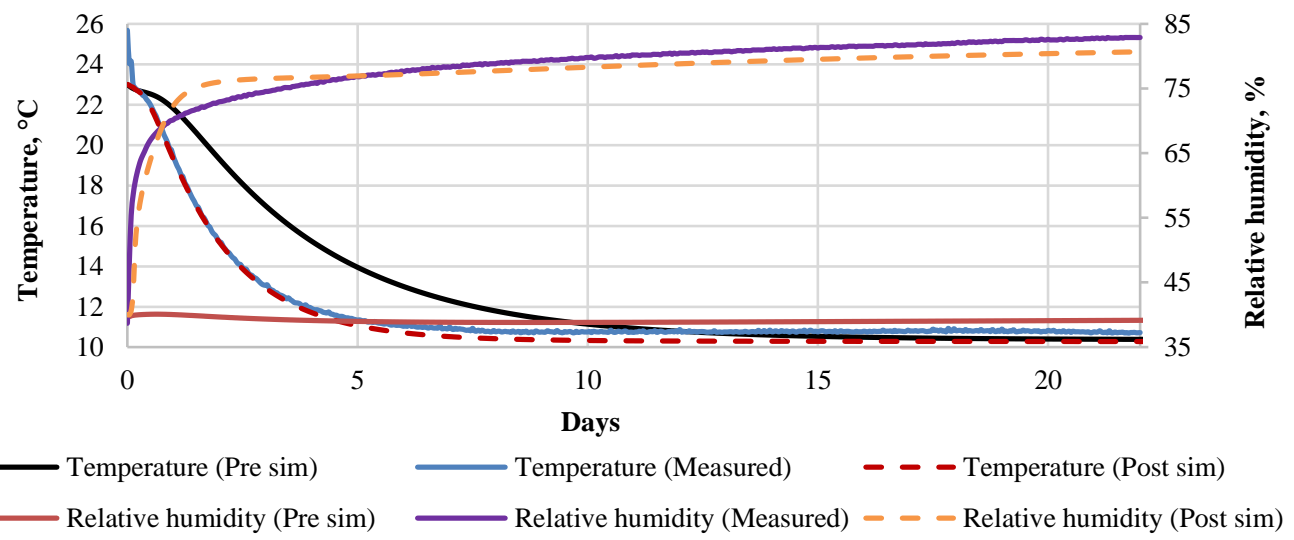

Fig. 11. Behaviour of temperature and relative humidity between masonry and mineral wool with vapour barrier $\left(s_{\mathrm{d}}=12 \mathrm{~m}\right)$ insulation layer: simulation before and after experiment, and measured results. 


\section{Discussion AND CONCluSions}

The goal of this research is to link hygrothermal simulation results with experimental results for internally insulated historic brick masonry to assess correlation between simulated and measured data as well as the most influential parameters.

We found the disagreement between measured and simulated hygrothermal performance of studied constructions. Test results showed that the relative humidity growth rate is high during the first test days for all materials and is slowing down when approaching equilibrium conditions. The temperature is decreasing at a slightly lower rate than relative humidity and is reaching equilibrium in about 5 days. The pre-test simulation showed a much lower growth rate of relative humidity and decrease rate for temperature compared to measured behaviour.

The parametric analysis that was carried out showed the most influential parameters on the hygrothermal behaviour of the whole construction. Parameters of all three insulation materials were adjusted to values supplied by material producers: thermal conductivity was increased by $8 \%$ for EPS and reduced for mineral wool by $10 \%$ and wood fiber by $10 \%$. Density was reduced for all three insulation materials to: mineral wool $24 \%$, wood fiber $67 \%$ and EPS $41 \%$, and water vapour diffusion resistance factor which was reduced for wood fiber by $30 \%$ and EPS by $69 \%$.

To reach acceptable results, thermal behaviour was changed by increasing thermal conductivity of bricks by $20 \%$ while reducing for mortar by $38 \%$. Specific heat capacity was reduced significantly for both bricks $(55 \%)$ and mortar $(38 \%)$.

The highest influence on moisture transport growth rate has initial relative humidity of materials: it was increased by $62 \%$ for bricks and $112 \%$ for mortar compared to pre-test simulation values. Masonry was dried out for 10 days prior to tests and it was too short a period of time to dry it out, so the moisture level was still higher at the beginning of tests than predicted during pre-test simulation. Other parameters that have impact on the moisture transport are liquid water conductivity at effective saturation and it was increased by $24 \%$ for bricks and mortar, and consequently water uptake coefficient has increased for bricks by $11 \%$ and $486 \%$ for mortar. Effective saturation was increased for about $111 \%$ for bricks and reduced $55 \%$ for mortar.

Material parameters as well as initial conditions of materials play an important role in the simulation but the latter is more influential in respect to material parameters.

Test results showed that under steady state conditions of an average outdoor climate of cold climate the highest relative humidity is reached by mineral wool $(82.9 \%)$, followed by wood fiber without vapour barrier $(80.5 \%)$, EPS $(79 \%)$, aerogel with vapour barrier $(78.2 \%)$, aerogel without vapour barrier $(73.3 \%)$ and wood fiber with vapour barrier $(72.7 \%)$. The temperature between the masonry wall and all insulation materials has stabilized on average at $+10{ }^{\circ} \mathrm{C}$.

Condensate tolerating wood fiber with vapour barrier reached $72.7 \%$ relative humidity and $80.5 \%$ in wood fiber without vapour barrier. Condensate limiting systems: EPS reached $79 \%$ and mineral wool with vapour barrier reached $82.9 \%$ relative humidity. In other insulation systems relative humidity has gone up to $73.3 \%$ (aerogel without vapour barrier) and $78.2 \%$ in aerogel with a vapour barrier.

There is no frost risk as relative humidity has not increased over $95 \%$ which is the state when capillary saturation starts. This might change if outdoor boundary conditions are changed, e.g. wind driven rain and solar radiation is applied on the surface. However, there is a risk of mold 
growth for insulation materials with biological origin such as wood fiber as it was detected during tests.

Considering all issues, our findings demonstrate that when internal insulation is applied to historic masonry in a cold climate, careful assessment of hygrothermal behaviour of combined historic masonry and insulation material wall construction has to be carried out. It is possible that simulation results will not conform precisely to actual measured data due to influence of values of initial moisture content of the wall as well as parameter value.

Future studies should include cyclic changes in boundary conditions, use of historic bricks and mortar with different properties.

\section{ACKNOWLEDGEMENT}

This study is carried out in the scope of EU financed project "RIBuild - Robust Internal Thermal Insulation of Historic Buildings" (637268 - RIBuild - H2020-EE-03-2014).

\section{REFERENCES}

[1] European Parliament and Council Directive 2010/31/EU on building energy efficiency. The Official Journal of the European Union 2010:153:13-35.

[2] Final energy consumption by end use in the EU-27. Available: www.eea.europa.eu/data-andmaps/indicators/energy-efficiency-and-energy-consumption-5/assessment/ [23.03.2017.]

[3] EU research project. RIBuild. Available: ribuild.eu [25.01.2018.]

[4] Miezis M., Zvaigznitis K., Stancioff N., Soeftestad L. Climate Change and Building Energy Efficiency - the key role of Residents. Environmental and Climate Technologies 2016. doi:10.1515/rtuect-2016-0004

[5] Ma Z., Cooper P., Daly D., Ledo L. Existing building retrofits: methodology and state-of-the-art. Energy Build. 2012:55:889-902. doi:10.1016/j.enbuild.2012.08.018

[6] Jerman M., Cerny R. Effect of moisture content on heat and moisture transport and storage properties of thermal insulation materials. Energy Build. 2012:53:39-46. doi:10.1016/j.enbuild.2012.07.002

[7] Zagorskas J., Paliulis G. M., Buriskiene M., Venckauskaite J., Rasmussen T. V. Energetic Refurbishment of Historic Brick Buildings: Problems and Opportunities. Environmental and Climate Technologies 2013. doi:10.2478/rtuect-2013-0012

[8] Purvins R., Biseniece E., Blumberga A. Laboratory investigation of Latvian historic brick and measurements of water movement in historic masonry walls. Energy Procedia 2017:113:327-332. doi:10.1016/j.egypro.2017.04.073

[9] Pasek J., Kesl P. Probabilistic assessment of failure risk of the building envelope thermally insulated from the inside. Applied Mathematics and Computation 2015:267:108-118. doi:10.1016/j.amc.2015.05.080

[10] Kass K., Blumberga A., Blumberga D., Zogla G., Kamenders A., Biseniece E. Pre-assessment method for historic building stock renovation evaluation. Energy Procedia 2017:113:346-353. doi:10.1016/j.egypro.2017.04.004

[11] Delphin software. Institute for Building Climatology. Available: www.bauklimatik-dresden.de/ [28.01.2018.]

[12] WUFI software. Fraunhofer institute for building physics. Available: wufi.de/de [28.01.2018.]

[13] Ibrahim M., Wurtz E., Biwole P. H., Achard P., Sallee H. (2014). Hygrothermal performance of exterior walls covered with aerogel-based insulating rendering. Energy and Buildings, 84: 241-251. doi:10.1016/j.enbuild.2014.07.039

[14] Haupl P., Fechner H. Hygric material properties of porous building materials. Journal of Thermal Environment \& Building Science 2003:26(3):259-284. doi:10.1177/109719603032799

[15] Vereecken E., Roels S. A comparison of the hygric performance of interior insulation systems: A hot box-cold box experiment. Building and Environment 2014:80:37-44. doi:10.1016/j.enbuild.2014.04.033

[16] Pavlik Z., Cerny R. Experimental assessment of hygrothermal performance of an interior insulation system using a laboratory technique simulating on-site conditions. Energy and Buildings 2008:40:673-678. doi:10.1016/j.enbuild.2007.04.019

[17] Johansson P., Geving S., Hagentoft C.-E., Jelle B. P., Rognvik E., Kalagasidis A. S., Time B. Interior insulation retrofit of a historic brick wall using vacuum insulation panels: Hygrothermal numerical simulations and laboratory investigations. Building and Environment 2014:79:31-45. doi:10.1016/j.buildenv.2014.04.014

[18] Morelli M., Nielsen T. R., Scheffler G. A., Svendsen S. Internal Insulation of Masonry Walls with Wooden Floor Beams in Northern Humid Climate. ASHRAE, 2010. 
[19] Biseniece E., Zogla G., Kamenders A., Purvins R., Kass K., Vanaga R., Blumberga A. Thermal performance of internally insulated historic brick building in cold climate: A long term case study. Energy and Buildings 2017:152:577-586. doi:10.1016/j.enbuild.2017.07.082

[20] Kloseiko P., Kalamees T., Arumargi E., Kallavus U. Hygrothermal Performance of a Massive Stone Wall with Interior Insulation: an In-Situ Study for Developing a Retrofit Measure. Energy Procedia 2015:78:195-200. doi:10.1016/j.egypro.2015.11.139

[21] Kloseiko P., Arumagi E., Kalamees T. Hygrothermal performance of internally insulated brick wall in cold climate: A case study in a historic school building. Journal of Building Physics 2015:38(5):444-464 doi:10.1177/1744259114532609

[22] Walker R., Pavia S. Thermal performance of a selection of insulation materials suitable for historic buildings. Building and Environment 2015:94:155-165. doi:10.1016/j.buildenv.2015.07.033

[23] Bianco L., Serra V., Fantucci S., Dutto M., Massolino M. Thermal insulating plaster as a solution for refurbishing historic building envelopes: First experimental results. Energy and Buildings 2015:95:86-91. doi:10.1016/j.enbuild.2014.11.016

[24] Galliano R., Ghazi Wakili K., Stahl T., Binder B., Daniotti B. Performance evaluation of aerogel-based and prelite-based prototyped insulations for internal thermal retrofitting: HMT model validation by monitoring at demo scale. Energy and Buildings 2016:126:275-286. doi:10.1016/j.enbuild.2016.05.021

[25] WTA Wissenschaftlich - Technische Arbeitsgemeinschaft für Bauwerkserhaltung und Denkmalpflege e.V. Innendämmung nach WTA I - Merkblatt 6-4: Planungsleitfaden. WTA Publications, 2014

[26] DIN 4108-3:2014-11. Wärmeschutz und Energie-Einsparung in Gebäuden - Teil 3: Klimabedingter Feuchteschutz Anforderungen, Berechnungsverfahren und Hinweise für Planung und Ausführung.

[27] EN 772-3:1998. Methods of test for masonry units. Determination of net volume and percentage of voids of clay masonry units by hydrostatic weighing.

[28] EN 772-13:2000. Methods of test for masonry units. Determination of net and gross dry density of masonry units (except for natural stone).

[29] Sedlbauer K., Krus M., Zillig W., Kunzel H. M. Mold growth prediction by computational simulation. Fraunhofer Institute for Building Physics, 2001.

[30] Viitanen H., Vinha J., Salminen K., Ojanen T., Peuhkuri R., Paajanen L., Lahdesmaki K. Moisture and bio-deterioration risk of building materials and structures. Journal of Building Physics 2010:33(3):201-224. doi:10.1177/1744259109343511

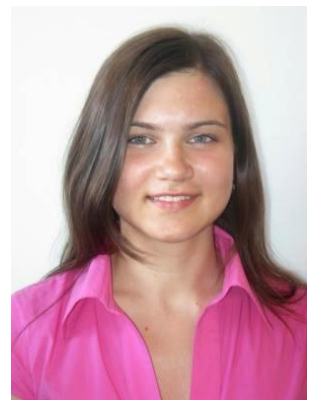

Edite Biseniece graduated from the Riga Technical University with professional bachelor degree in civil engineering and gained civil engineer qualification; in 2014 she obtained master degree in environmental engineering at Riga Technical University and at Vilnius Gediminas Technical University. In 2010 as an exchange student Edite studied in Technical University of Denmark.

Author has a background in civil engineering, and in environmental engineering. In 2012 she in master studies Edite has been focusing on indoor air quality and energy efficiency of renovated residential buildings. Work on residential building energy efficiency issues is continued in $\mathrm{PhD}$ studies.

ORCID: https://orcid.org/0000-0001-8301-2442

E-mail: edite.biseniece@rtu.lv

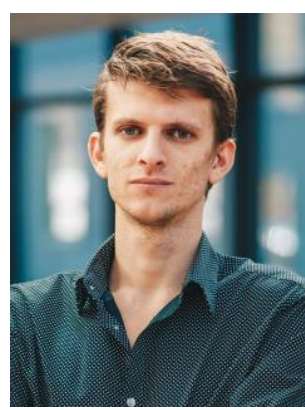

Ritvars Freimanis received B.sc. degree in Environmental Science at Environmental Science, Riga Technical University. His Bachelor thesis were about laboratory tests on internally insulated historic masonry walls. Now Ritvars continuous to study in Master program in Environmental Science.

Since 2017 he works as Scientific assistant at Institute of Environmental and Energy Systems in Riga Technical University, Riga. He is involved in EU research project RIBuild that develops guidelines on how to install thermal insulation on historic buildings.

E-mail: ritvars.freimanis_1@ @rtu.lv 

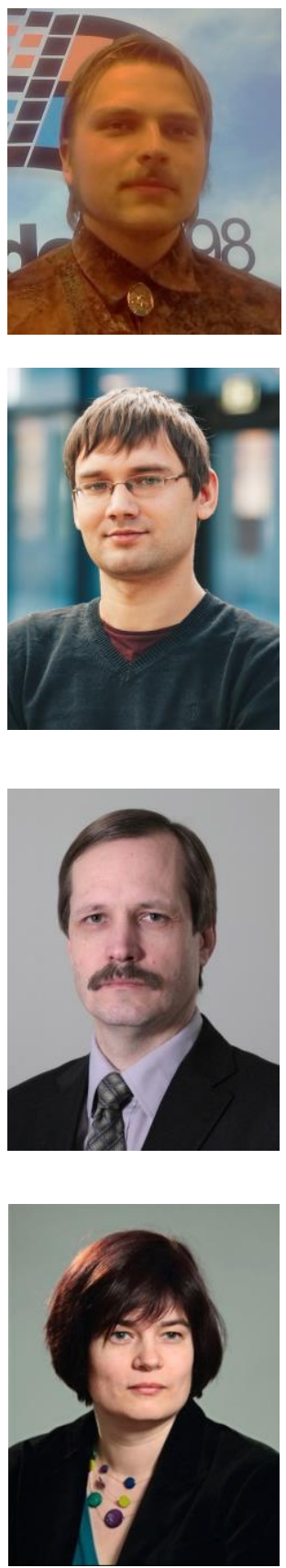

Reinis Purvins received B.sc. degree in Environmental Science at Riga Technical University in 2016. Worked in Institute of Energy Systems and Environment from 2015-2017. His work in IESE was related to research projects such as EU research project RIBuild.

ORCID: https://orcid.org/0000-0001-5819-8601

Armands Gravelsins received Bachelor degree in Environmental Science at Riga Technical University in 2015. He received Master degree in Environmental Science by graduating both Riga Technical University and Vilnius Gediminas Technical University in 2017. Topic of the Master thesis was "Forest industry development towards bioeconomy: a system dynamics model". In 2017 he started Ph.D. studies in Riga Technical University. Since 2014 Armands Gravelsins has been working at Institute of Energy Systems and Environment as a Researcher. He is an author of 11 scientific publications and conference papers indexed in SCOPUS and Web of Science, and a co-author of 3 scientific monographs. The main research areas are renewable energy, energy sector transition towards low carbon energy, bioeconomy, system dynamics modelling. In 2015 Armands Gravelsins received "Latvenergo" award for research in energy sector.

ORCID: https://orcid.org/0000-0002-4936-5233

Aivars Pumpurs received a degree in electrical engineering from Riga Politechnical Institute in 1986. Since 2008 works at Department of Automatic electric drive in Riga Technical University as practical associate professor.

Author has worked in research projects regarding wind and hydrogen autonomous power system and energy efficiency.

ORCID: https://orcid.org/0000-0002-1593-8611

E-mail: Aivars.Pumpurs@ rtu.lv

Andra Blumberga, Dr.sc.ing., professor, works for Institute of Energy Systems and Environments, Riga Technical university since 2001.

She has been working with energy efficiency since 1992. Her main research interest is energy efficiency both from technical and policy sides.

She has managed many national and international research and other projects since 1999, e.g. "Assessment on energy efficiency and use of renewable energy sources in Latvia by 2020", Climate Technology development modeling in energy sector", "Energy strategy 2030 for Latvia", "System Dynamics modeling for energy sector in Latvia".

She has been working as the World Bank energy expert for development of the Green Investment Scheme in Latvia. She is author of more than 80 publications and 14 monographs.

ORCID: https://orcid.org/0000-0002-4712-4794 